\title{
QIKJS-Part.I.I
}

\section{Qualitative Inquiry of Korean Judicial System}

\author{
Kiyoung Kim \\ Professor of Law and Public Policy \\ Dept. of Law, Chosun University \\ Gawng-ju South Korea
}

\section{An Introductory Statement}

It might be true that many of graduate students despairingly grappled with the negative emotions that can accompany slogging through a long form project like a dissertation. It would be the kind of mixed feelings, such as guilt, self-loathing, and a healthy dose, but I don't wanna, primarily. The creation of abstracts, however, would not be same that it could be a kind of moment of swagger upon the exhaustive work of boisterous chapters with which they have to tackle over long time. It represents a crystallization of years of doctoral studies, and key attraction of readership whether to read further on chapters or download a research piece. Provided that the research work eventually would be destined to adding his or her new findings to the world knowledge web, the abstract will demonstrate a creativity of findings as well as clarity and readability, conciseness, and interconnectedness with the existing knowledge. The social science research network, a social network of researchers and called SSRN in abbreviation, manages on the cause of open access, which provides its e-library with inside index system, and compiles a ranking based on the downloading. If the interested researchers had been attracted by the abstract of articles or working papers, then he is expected to download them, the number of which bases their author and institutional ranking. Given the ranking would be interested publicly, this simply shows the importance - at least, relevance -- of abstract in assessing the attraction of articles. The abstract represents an expected quality of article and its importance relating with the theme or issues of scholarly attention. That probably would be an assumption of SSRN in its deals with such ranking. Although the abstracts could not show the ways of specific deals within the research piece and its deep implication for the related researchers, they could be a beacon or at least prelude, especially because the researchers in the interested fields are generally experienced and well exposed to the nature of work even with a short introduction, such as abstracts (Rudestam \& Newton, 2015). Along with the simple alignment showed in the abstracts, they could perhaps immediately know the nature and quality of article in advance and before downloading although that would not perfectly be proven all of cases. One other illustration about the importance of abstracts would be the practice of prestigious journals, such as Science or Nature, which provides a news type summary of new findings besides the main article. That would differ from the abstracts in terms of content, but would be a same idea with the requirement of abstracts for the articles and dissertations. The books 
may not include an abstract page, instead, be indebted to the table of contents for similar purpose.

According to the Walden guide, the key components of sample abstracts would include seven elements, which are (i) research problem and importance (ii) purpose of research (iii) theoretical/conceptual framework (iv) key research questions (v) research design, methods, data analysis (vi) key findings, conclusions, recommendations (vii) implications for social change (2013a). The abstract also needs to be prepared with important considerations that the content has no holes in information while it also should not be overly vague. It demonstrates continuity by providing a logical connection among elements and sequence in conducting research (2013a). The title is important since it attracts reader's attention, basis for the key words search and assists with information recall for the readers of chapters (2013a). Since the abstract is a part of dissertation, it is expected to be written in its scholarly language. This does not mean that the abstract language should be same with that of main body of article or dissertation although they normally are so. For example, Korean works often require English and Korean versions of abstract for their articles and dissertations. That would be the kind of linguistic practice likely in UN or international organizations and Francophone countries. Instead it means a tone and writing style as cohesive through the abstracts and chapters thereafter. It typically would be practiced that no indented and one long paragraph comes through the end of abstract and the abstract must be written in concise, accurate, readable and correct English (2013a). The author also ensures that each sentence adds value to the reader's understanding of the research, meaning that no unnecessary sentences take place in it.

\section{Reflections}

The precepts and comment from the work of Mills seem to be the kind of textual for the researchers of social science (1959). While the end of our endeavor is the human variety that we are always writing about, the minds of researcher constantly reflect if he would have exercised a "good craftsmanship." His other precept is that thinking is important and the kind of struggle for order and at the same time for comprehensiveness (1959). I agree on his points, and like to add my daily experience. Actually I am an avid weekend TV viewer for the channels of religion. Korean TV provides several channels for that purpose, say, two evangelicals, one catholic, one Buddhism and final of Korean Originalism. One instructor of method class once said that the work of research design would likely be the kind of work on decoration for the Christmas tree. Then we would celebrate the grace of Jesus through our work. It is especially felt these days that Korean priests in TV channels had taught the sacrifice of Christ instead of sinned ours. The Christianity certainly had an impression of power to evangelize every corner of disciples suited to their business and profession. The teaching guides them to be a wholeness of big child who will be empowered to continue on his or her thorny world or that of sufferance. Since they would be reinvigorated with the sacrifice, parental auspice, and generosity with every pardons of Christ, it is highly suited to the individuals over various professions and social conditions. This context may pertain to the good craftsmanship suggested by Mills. Nevertheless, his other comment on the primacy of thinking seems to be explained more adequately by ascribing to the Korean Originalism or Buddhism. The channel of Korean Originalism boasts his title as Sang Saeng - meant as 
"mutual survival" in English. Now the individual context of empowering within the

Christianity turns to see a connection with others, so that the decorator for the research design seeks the order and comprehensiveness. As we see, Buddhism also bases their preaching on the meditation and sufferance through the fantasy and for the end of spiritual composure. The process of these mentality seems fairly be similar to the dissertator. While the empowering from Christianity may encourage that the extensive field work is feasible on one hand, the meditation would be kind of thinking for order and comprehensiveness in the Mill's case (1959). The Eureka moment is the kind of fantasy for the qualitative researcher as if trained with the Buddhist meditation, which will finally be returned to the composure upon write-up of empirical data and understanding (Patton, 2002). Since the anatomy of religion may not be good for the spiritual lives, the elements of each religion likely guide the path of researchers in various projects (Kim, 2015a,b,c).

Attachment: For the week discussion, attached please find the Abstract. 


\section{References}

Kim, Kiyoung, An Attempt on the Methodological Composure: Between the Number and Understanding, Nature and Construction (December 12, 2015a). K. Kim, An Attempt on the Methodological Composure: Between the Number and Understanding, Nature and Construction, Chosun University, 2015. Available at SSRN: https://ssrn.com/abstract $=2702701$

Kim, Kiyoung, Concerning the Research and Science (April 10, 2015b). Available at SSRN: https://ssrn.com/abstract=2592858 or http://dx.doi.org/10.2139/ssrn.2592858

Kim, Kiyoung, The Research Design and Methodologidal Deliberation (December 23, 2015c). Available at SSRN: https://ssrn.com/abstract $=3305760$

Mills, C. W. (1959). On intellectual craftsmanship In The sociological imagination (pp. 195227). New York, NY: Oxford University Press.

Patton, M. Q. (2002). Qualitative research and evaluation methods (3rd ed.). Thousand Oaks, CA: Sage Publications, Inc.

Rudestam, K. E., \& Newton, R. R. (2015). Surviving your dissertation: A comprehensive guide to content and process (4th ed.). Thousand Oaks, CA: Sage. ISBN: 978-14522-6097-6

Walden University, School of Public Policy and Administration. (2013a). SPPA abstract guidelines [PowerPoint]. Minneapolis, MN: Walden University. 